\title{
MAKALAH \\ PENYAKIT MENULAR DAN VIRUS CORONA
}

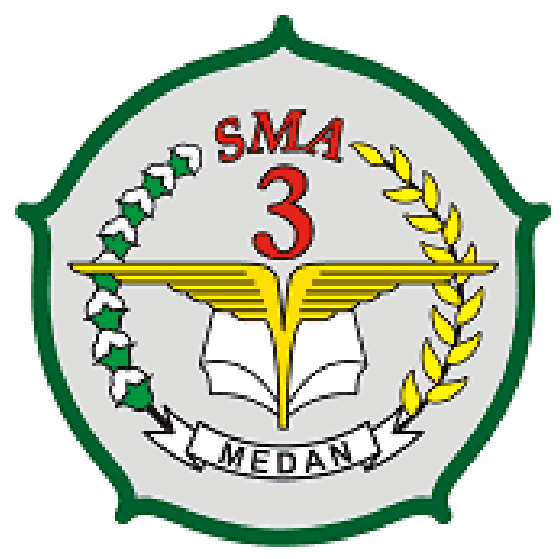

NAMA: AZRAH KAMILA

KELAS: X MIA 6

SMA NEGERI 3 MEDAN

2020 


\section{KATA PENGANTAR}

Dengan mengucapkan puji syukur ke hadiran Tuhan Yang Maha Esa memberikan rahmatNya kepada saya sehingga saya dapat menyelesaikan makalah dengan judul "Penyakit Menular Dan Virus Corona' ini.

Makalah ini penulis buat untuk melengkapi tugas pelajaran PJOK. Saya ucapkan terima kasih kepada semua pihak yang telah membantu dalam penyusunan makalah ini. Dan saya juga menyadari akan pentingnya sumber bacaan dan referensi internet yang telah membantu dalam memberikan informasi yang akan menjadi bahan makalah. Saya juga mengucapkan terima kasih kepada bapak guru Suyono S.Pd, M.Or sebagai guru bidang studi yang telah banyak memberi petunjuk dan semua pihak yang telah memberikan arahan serta bimbingannya selama ini sehingga penyususan makalah dapat dibuat dengan sebaikbaiknya.

Shalawat serta salam tidak lupa kita sampaikan kepada Rasulullah SAW. M eskipun penulis telah beusaha dengan sebaik-baiknya dalam menyusun makalah ini, namun penulis menyadari bahwa masih banyak kekurangan baik dari sistematika maupun penyusunan kalimatnya. Dengan demikian, penulis mengharapkan saran dan masukan yang membangun, demi kesempurnaan makalah ini, semoga makalah ini dapat bermanfaat

Medan, 08 Mei 2020

Azrah Kamila 


\section{DAFTAR ISI}

Judul

Kata pengantar

Daftar isi

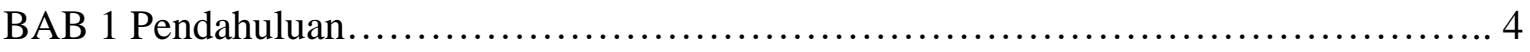

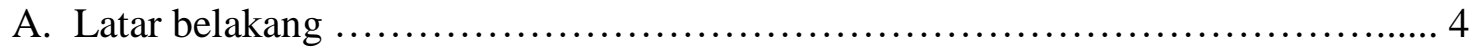

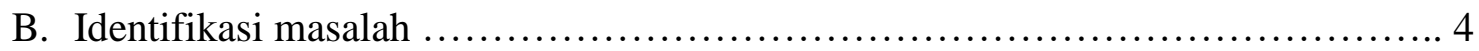

C. Batasan masalah ............................................................. 5

D. Rumusan masalah ........................................................... 5

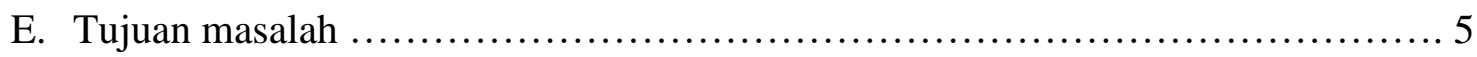

Bab 2 Pembahasan ................................................................... 6

A. Kajian materi , Hakikat materi ............................................. 6

B. Pengertian penyakit menular ........................................... 6

C. Macam- macam penyakit menular........................................ 6

D. Cara penyebaran penyakit menular ..................................... 8

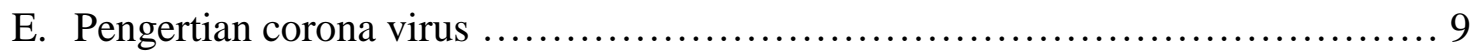

F. Asal muasal corona virus .................................................... 9

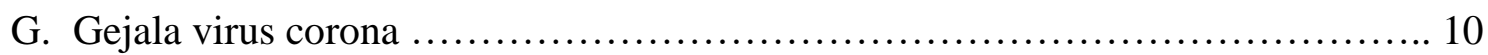

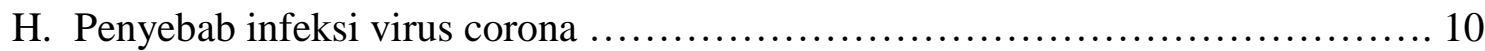

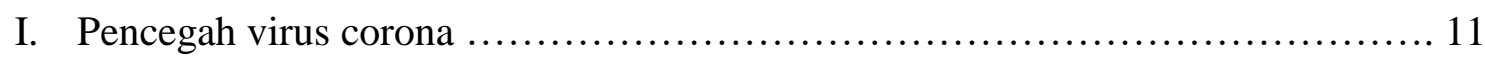

Bab 3 Penutup

A. Kesimpulan................................................................ 12

B. Daftar pustaka......................................................... 13 


\section{PENDAHULUAN}

A. Latar Belakang

Penyakit menular menjadi salah satu penyebab utama kematian di Dunia. Penyebabnya munculnya penyakit baru (new emerging disease) dan munculnya kembali penyakit menular yang lama (re-emerging disease) membuat Indonesia menanggung beban berlebih dalam penanggulangan penyakit (triple burden disease) (Kemenkes, 2013). Kondisi ini semakin buruk dengan kondisi lingkungan yang tidak sehat menyebabkan beberapa penyakit infeksi akut yang berbahaya menyerang manusia seperti penyakit yang bersumber pada binatang seperti leptospirosis (Widarso dan Wilfried, 2008).

Menurut Internasional Leptospirosis Society (ILS) Indonesia merupakan negara dengan insiden leptospirosis berada pada peringkat 3 di bawah negara Cina dan India. Angka kematian leptopirosis pada penderita usia 50 tahun keatas dapat mencapai $56 \%$ (CFR). Kejadian Luar Biasa (KLB) insiden penyakit leptospirosis mencapai lebih dari 100 per 100.000 penduduk per tahun (WHO, 2010). Angka kematian leptospirosis pada penderita usia 50 tahun keatas dapat mencapai 56\% ( WHO, 2010). Berdasarkan data Profil Kesehatan Indonesia tahun 2010 hanya 7 provinsi yang melaporkan kasus suspek leptospirosis yaitu provinsi DKI Jakarta, Jawa Barat, Jawa Tegah, DI Yogyakarta, Bengkulu, Kepulauan Riau dan Sulawesi Selatan. Rendahnya angka pelaporan kasus leptospirosis dikarenakan kesulitan dalam diagnosis penyakit leptospirosis sehingga menyebabkan sulitnya upaya dalam pemberantasan (Kementrian Kesehatan RI, 2013).

Latar belakang virus Corona atau COVID-19, kasusnya dimulai dengan pneumonia atau radang paru-paru misterius pada Desember 2019. Kasus ini diduga berkaitan dengan pasar hewan Huanan di Wuhan yang menjual berbagai jenis daging binatang, termasuk yang tidak biasa dikonsumsi, misal ular, kelelawar, dan berbagai jenis tikus. Kasus infeksi pneumonia misterius ini memang banyak ditemukan di pasar hewan tersebut. Virus Corona atau COVID-19 diduga dibawa kelelawar dan hewan lain yang dimakan manusia hingga terjadi penularan. Coronavirus sebetulnya tidak asing dalam dunia kesehatan hewan, tapi hanya beberapa jenis yang mampu menginfeksi manusia hingga menjadi penyakit radang paru.

Sebelum COVID-19 mewabah, dunia sempat heboh dengan SARS dan MERS, yang juga berkaitan dengan virus Corona. Dengan latar belakang tersebut, virus Corona bukan kali ini saja membuat warga dunia panik. Memiliki gejala yang sama-sama mirip flu, virus Corona berkembang cepat hingga mengakibatkan infeksi lebih parah dan gagal organ.

B. Identifikasi Masalah

- Terjadinya penularan penyakit dengan mudah

- Adanya wabah yang menggempar dunia yaitu virus corona 
C. Batasan Masalah

Pembatasan suatu masalah digunakan untuk menghindari adanya penyimpangan maupun pelebaran pokok masalah agar penelitian tersebut lebih terarah dan memudahkan dalam pembahasan sehingga tujuan penelitian akan tercapai. Beberapa batasan masalah dalam penelitian ini adalah sebagai berikut:

- Luas lingkup hanya meliputi tentang penyakit menular dan virus corona.

- Informasi yang disajikan: menyebarnya penyakit menular, proses munculnya wabah virus corona .

D. Rumusan Masalah

1. Apa itu penyakit menular?

2. Apa saja jenis atau macam - macam penyakit menular?

3. Bagaimana ara penyebaran penyakit menular?

4. Apa itu virus corona?

5. Darimana asal muasal virus corona?

6. Apa saja gejala virus corona?

7. Apa saja penyebab infeksi virus corona?

8. Bagaiman pencegahan virus corona?

E. Tujuan Masalah

1. Mengethui tentang apa itu penyakit menular

2. Mengetahui jenis atau macam- macam penyakit menular

3. Mengetahui cara penyebaran penyakit menular

4. Mengetahui tentang apa itu virus corona

5. Mengetahui asal muasal virus corona

6. Mengetahui gejala- gejala virus corona

7. Mengetahui apa saja penyebab infeksi virus corona

8. Mengetahui bagaimana pencegahan virus corona 


\section{PEMBAHASAN}

\section{Kajian Materi}

\section{Hakikat Materi}

\section{Penyakit Menular}

1. Pengertian penyakit menular

Penyakit menular merupakan penyakit infeksi yang disebabkan oleh mikroorganisme, seperti virus, bakteri, parasit, atau jamur, dan dapat berpindah ke orang lain yang sehat. Beberapa penyakit menular yang umum di Indonesia dapat dicegah melalui pemberian vaksinasi serta pola hidup bersih dan sehat. Penyakit menular dapat ditularkan secara langsung maupun tidak langsung. Penularan secara langsung terjadi ketika kuman pada orang yang sakit berpindah melalui kontak fisik, misalnya lewat sentuhan dan ciuman, melalui udara saat bersin dan batuk, atau melalui kontak dengan cairan tubuh seperti urine dan darah. Orang yang menularkannya bisa saja tidak memperlihatkan gejala dan tidak tampak seperti orang sakit, apabila dia hanya sebagai pembawa (carrier) penyakit.

\section{Penyakit Menular yang Umum di Indonesia}

Penyakit menular umumnya lebih berisiko mengenai orang yang memiliki daya tahan tubuh lemah dan tinggal di lingkungan dengan kondisi kebersihan yang kurang baik. Penyakit menular juga dapat meningkat pada waktu tertentu, misalnya pada musim hujan atau banjir .Gejala dan tanda penyakit penyakit menular tergantung pada jenis mikroorganisme yang menyebabkan penyakit infeksi. Di Indonesia, penyakit menular yang umumnya terjadi antara lain:

- Infeksi saluran pernapasan akut (ISPA)

Infeksi saluran pernapasan dapat menyerang hidung, tenggorokan, saluran napas, dan paru-paru. ISPA diawali dengan panas disertai salah satu atau lebih gejala tenggorokan sakit atau nyeri telan, batuk kering atau berdahak, dan pilek. Kondisi ini seringkali disebabkan oleh virus, namun bisa juga disebabkan oleh bakteri. ISPA yang disebabkan oleh infeksi virus biasanya akan membaik dalam waktu 3-14 hari. ISPA dapat dicegah dengan berperilaku hidup bersih dan sehat, membiasakan cuci tangan. Perhatikan pula etika batuk dan bersin, serta gunakan masker agar virus dan bakteri tidak menular ke orang lain.

- Diare

Diare merupakan gangguan buang air besar (BAB). Penyakit ini ditandai dengan BAB lebih dari tiga kali sehari, disertai rasa mulas, dengan konsistensi tinja cair, dan dapat disertai dengan darah dan atau lendir. Diare mungkin dianggap sepele padahal dapat 
berpotensi kematian, terutama pada balita. Diare menular melalui air, tanah, atau makanan yang terkontaminasi virus, bakteri, atau parasit.

- $\mathrm{TB}$

TB (tuberkulosis) masih menjadi pembunuh terbanyak di antara penyakit menular. Berdasarkan data WHO tahun 2017, diperkirakan ada 1 juta kasus TB di Indonesia. TB disebabkan oleh bakteri yang menyerang paru-paru, namun bakteri tersebut bisa juga menyerang bagian tubuh lain seperti tulang dan sendi, selaput otak (meningitis TB), kelenjar getah bening (TB kelenjar), dan selaput jantung. Bakteri ini ditularkan melalui udara saat penderita batuk atau bersin. TB dapat dicegah melalui pemberian vaksin BCG.

- DBD

Demam dengue merupakan penyakit menular yang disebabkan oleh infeksi virus dengue. Virus ini menginfeksi manusia melalui gigitan nyamuk Aedes aegypti dan Aedes albopictus. Demam dengue merupakan penyakit musiman yang umum terjadi di negara beriklim tropis. Di Indonesia, penyakit menular ini lebih banyak terjadi di saat musim hujan. Demam dengue dapat berkembang menjadi kondisi yang lebih berat yaitu demam berdarah dengue (DBD).

- Cacingan

Cacingan disebabkan oleh cacing tambang, cacing pita, dan cacing kremi yang menginfeksi usus. Cacingan dapat mengakibatkan anemia (kurang darah), lemas, dan mengantuk, sehingga produktivitas menurun. Hal ini karena cacing menyerap nutrisi yang dibutuhkan tubuh seperti karbohidrat dan protein. Pada wanita hamil, cacingan dapat mengakibatkan berat bayi lahir rendah dan masalah pada persalinan. Cacingan menular melalui kontak langsung, misalnya saat tangan yang kotor dimasukkan ke dalam mulut, atau secara tidak langsung saat Anda menyentuh makanan atau benda yang mengandung telur cacing.

- Penyakit Kulit

Kudis dan kurap menjadi penyakit kulit menular yang banyak diderita oleh masyarakat Indonesia. Penularan penyakit ini terkait dengan kebersihan diri dan lingkungan.

Selain itu, kusta juga masih diderita oleh sebagian masyarakat Indonesia. Gejalanya berupa bercak putih atau merah di kulit yang mati rasa. Kusta dapat menular melalui percikan air liur, bersin, maupun kontak melalui kulit yang luka. Penyakit ini dapat menyebabkan cacat permanen jika tidak diobati sejak dini.

- Malaria

Malaria merupakan penyakit menular yang disebabkan oleh parasit dan juga ditularkan melalui gigitan nyamuk. Penderita malaria umumnya menunjukkan gejala demam, menggigil, sakit kepala, berkeringat, nyeri otot, disertai mual dan muntah. Malaria termasuk penyakit endemik dengan daerah yang masih memiliki kasus yang 
tinggi berada di wilayah Indonesia timur. Penduduk yang tinggal di wilayah endemik malaria memiliki risiko tertinggi tertular penyakit ini.

\section{- Difteri}

Difteri adalah penyakit menular yang disebabkan oleh bakteri. Gejalanya berupa demam dan peradangan pada selaput saluran pernapasan bagian atas, hidung, serta kulit. Pada tahun 2017, difteri pernah menjadi kasus luar biasa di Indonesia. Kondisi ini terjadi karena diduga terdapat kelompok yang mudah tertular difteri akibat tidak mendapatkan vaksinasi atau status vaksinasinya tidak lengkap.

\section{- Cacar Air}

Cacar air adalah penyakit yang dapat menular dengan cepat dan mudah. Namun pada umumnya cacar air hanya akan menyerang pada anak-anak. Tapi tidak menutup kemungkinan orang dewasa juga akan mengalami hal ini. Cacar air dapat dicegah dengan melakukan vaksinasi. Pemberian vaksin ini dilakukan agar orang terhindari dari resiko tertular virus cacar air atau menularkan cacar air kepada orang lain. Pencegahan lain yang juga perlu dilakukan adalah mengisolasi penderita cacar air dari tempat-tempat umum agar tidak menyebarkan kepada orang lain

Pencegahan penyakit menular juga bisa diupayakan melalui kebiasaan hidup sehat. Di antaranya tidak meludah sembarangan, mencuci tangan, tidak memakai peralatan pribadi bersamaan dengan orang lain, serta mengonsumsi makanan sehat dan bergizi untuk meningkatkan daya tahan tubuh terhadap penyakit.

Cara penyebaran penyakit menular secara umum yaitu :

1. Media Langsung dari Orang terjangkit kepada orang lain (biasanya melalui permukaan kulit)

2. Media udara juga bisa menjadi media dalam penularan penyakit secara langsung atau tidak langsung, karena udara sisa pernafasan tersebut bisa saja mengandung virus atau bakteri dan terkandung dalam air yang disebut dengan borne disease.

3. Media air pun bisa menjadi penularan penyakit secara langsung maupun tidak langsung.

4. Selain metode penyebaran di atas, penyakit menular juga dapat menyebar melalui gigitan hewan, atau kontak fisik dengan cairan tubuh hewan, serta melalui makanan dan minuman yang terkontaminasi mikroorganisme penyebab penyakit. 


\section{COVID 19}

\section{Pengertian}

Virus Corona atau severe acute respiratory syndrome coronavirus 2 (SARS-CoV-2) adalah virus yang menyerang sistem pernapasan. Penyakit karena infeksi virus ini disebut COVID19. Virus Corona bisa menyebabkan gangguan ringan pada sistem pernapasan, infeksi paru-paru yang berat, hingga kematian. Severe acute respiratory syndrome coronavirus 2 (SARS-CoV-2) yang lebih dikenal dengan nama virus Corona adalah jenis baru dari coronavirus yang menular ke manusia. Walaupun lebih banyak menyerang lansia, virus ini sebenarnya bisa menyerang siapa saja, mulai dari bayi, anak-anak, hingga orang dewasa, termasuk ibu hamil dan ibu menyusui.

Infeksi virus Corona disebut COVID-19 (Corona Virus Disease 2019) dan pertama kali ditemukan di kota Wuhan, China pada akhir Desember 2019. Virus ini menular dengan sangat cepat dan telah menyebar ke hampir semua negara, termasuk Indonesia, hanya dalam waktu beberapa bulan.

Coronavirus adalah kumpulan virus yang bisa menginfeksi sistem pernapasan. Pada banyak kasus, virus ini hanya menyebabkan infeksi pernapasan ringan, seperti flu. Namun, virus ini juga bisa menyebabkan infeksi pernapasan berat, seperti infeksi paru-paru (pneumonia). Selain virus SARS-CoV-2 atau virus Corona, virus yang juga termasuk dalam kelompok ini adalah virus penyebab Severe Acute Respiratory Syndrome ( $\underline{\text { SARS }})$ dan virus penyebab Middle-East Respiratory Syndrome (MERS). Meski disebabkan oleh virus dari kelompok yang sama, yaitu coronavirus, COVID-19 memiliki beberapa perbedaan dengan

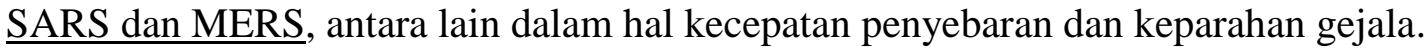

Pandemi ini telah menyebabkan gangguan sosioekonomi global, penundaan atau pembatalan acara olahraga dan budaya dan kekhawatiran luas tentang kekurangan persediaan barang yang mendorong pembelian panik. Misinformasi dan teori konspirasi tentang virus telah menyebar secara daring dan telah terjadi insiden xenophobia dan rasisme terhadap orang Tiongkok dan orang-orang Asia Timur atau Asia Tenggara lainnya.

\section{$>$ Asal Muasal Virus Corona}

Virus corona jenis baru yang tengah menyerang masyarakat dunia saat ini dalam istilah kedokteran disebut sebagai 2019 Novel Coronavirus (2019-nCoV). Dikutip dari Center for Disease Control and Prevention, cdc.gov, virus corona merupakan jenis virus yang diidentifikasi sebagai penyebab penyakit pada saluran pernapasan, yang pertama kali terdeteksi muncul di Kota Wuhan, Tiongkok.

Virus ini diketahui pertama kali muncul di pasar hewan dan makanan laut di Kota Wuhan. Dilaporkan kemudian bahwa banyak pasien yang menderita virus ini dan ternyata terkait dengan pasar hewan dan makanan laut tersebut. Orang pertama yang jatuh sakit akibat virus ini juga diketahui merupakan para pedagang di pasar itu. 
Dikutip dari $B B C$, koresponden kesehatan dan sains $B B C$, Michelle Roberts and James Gallager mengatakan, di pasar grosir hewan dan makanan laut tersebut dijual hewan liar seperti ular, kelelawar, dan ayam. Mereka menduga virus corona baru ini hampir dapat dipastikan berasal dari ular. Diduga pula virus ini menyebar dari hewan ke manusia, dan kemudian dari manusia ke manusia.

\section{Gejala Virus Corona}

Gejala awal infeksi virus Corona atau COVID-19 bisa menyerupai gejala flu, yaitu demam, pilek, batuk kering, sakit tenggorokan, dan sakit kepala. Setelah itu, gejala dapat hilang dan sembuh atau malah memberat. Penderita dengan gejala yang berat bisa mengalami demam tinggi, batuk berdahak bahkan berdarah, sesak napas, dan nyeri dada. Gejala-gejala tersebut muncul ketika tubuh bereaksi melawan virus Corona.

Secara umum, ada 3 gejala umum yang bisa menandakan seseorang terinfeksi virus Corona, yaitu:

- Demam (suhu tubuh di atas 38 derajat Celsius)

- Batuk kering

- Sesak napas

Ada beberapa gejala lain yang juga bisa muncul pada infeksi virus Corona meskipun lebih jarang, yaitu:

- Diare

- Sakit kepala

- Konjungtivitis

- Hilangnya kemampuan mengecap rasa atau mencium bau

- Ruam di kulit

Gejala-gejala COVID-19 ini umumnya muncul dalam waktu 2 hari sampai 2 minggu setelah penderita terpapar virus Corona.

\section{Penyebab Infeksi Virus Corona}

Infeksi coronavirus disebabkan oleh virus corona itu sendiri. Kebanyakan virus corona menyebar seperti virus lain pada umumnya, seperti:

- Percikan air liur pengidap (bantuk dan bersin).

- Menyentuh tangan atau wajah orang yang terinfeksi.

- Menyentuh mata, hidung, atau mulut setelah memegang barang yang terkena percikan air liur pengidap virus corona.

- Tinja atau feses (jarang terjadi)

Khusus untuk COVID-19, masa inkubasi belum diketahui secara pasti. Namun, rata-rata gejala yang timbul setelah 2-14 hari setelah virus pertama masuk ke dalam tubuh. Di samping itu, metode transmisi COVID-19 juga belum diketahui dengan pasti. Awalnya, virus corona 
jenis COVID-19 diduga bersumber dari hewan. Virus corona COVID-19 merupakan virus yang beredar pada beberapa hewan, termasuk unta, kucing, dan kelelawar.

\section{Pencegahan Virus Corona}

Kasus infeksi virus Corona atau COVID-19 yang masih mewabah bisa dicegah dengan cara yang sederhana. Berikut empat cara pencegahan virus Corona atau COVID-19,

\section{Cuci Tangan}

Saat cuci tangan dengan sabun dan air minimal dilakukan selama 20 detik. Jika tak ada air dan sabun bisa dengan hand sanitizer dengan kandungan alkohol minimal 60 persen. Cuci tangan harus dilakukan sebelum dan setelah beraktivitas.

\section{Jangan Menyentuh Tempat Umum}

Ketika berada di fasilitas umum, sebaiknya jangan menyentuh tombol lift, pegangan pintu, pegangan tangga atau eskalator. Jika harus menyentuh, sebaiknya gunakan tisu atau lengan baju dan segera cuci tangan setelahnya.

\section{Hindari Keramaian}

Kasus infeksi virus Corona atau COVID-19 mudah menyerang saat di tempat ramai. Karena itu, usahakan tidak berada di keramaian apalagi dalam ruangan berventilasi buruk. Bila terpaksa berada di keramaian, jangan sembarangan menyentuh wajah, hidung, dan mata, apalagi bila belum cuci tangan.

\section{Rajin Membersihkan Rumah}

Bersih-bersih rumah menggunakan cairan disinfektan menjadi upaya lain mencegah kasus infeksi virus Corona atau COVID-19. Setelah cara-cara pencegahan ini dilakukan, jangan lupa gunakan masker saat beraktivitas di luar rumah. 


\section{KESIMPULAN}

Berdasarkan uraian diatas dapat dibilang penyakit menular menjadi salah satu penyakit yang menyebabkan tingkat kematian di dunia. Penyakit menular itu penyakit infeksi yang disebabkan oleh mikroorganisme, seperti virus, bakteri, parasit, atau jamur, dan dapat berpindah ke orang lain yang sehat. Penyakit menular umumnya mudah di diagnosa dan sangat mudah ditularkan.

Covid 19 merupakan salah satu jenis penyakit yang bisa menular yang mana pertamanya penyakit ini berasal dari binatang akan tetapi dia menjangkit ada manusia bahkan bisa menyebar dari satu manusia ke manusia yang lain dan penyakit covid 19 ini menyerang pada sistem pernafasan. Covid 19 merupakan salah satu penyakit yang penyebarannya sangat begitu cepat bahkan lebih cepat dari penyakit MERS atau memiliki kepanjangan middle- east respiratory syndrome dan SARS atau memiliki kepanjangan severe acute respiratory syndrome. 


\section{DAFTAR PUSTAKA}

https://www.alodokter.com/penyakit-menular-yang-umum-di-indonesia

https://www.alodokter.com/virus-corona

https://bali.idntimes.com/health/medical/denny-adhietya/asal-muasal-dan-perjalanan-virus-coronadari-wuhan-ke-seluruh-dunia-regional-bali/3

https://www.halodoc.com/kesehatan/coronavirus 